\title{
Opening the black box of participation in medicine and healthcare
}





\title{
Opening the black box of participation in medicine and healthcare
}

\section{Lorenzo Del Savio}

Research Fellow, Institute for Experimental Medicine,

Department of Biomedical Ethics, Christian-Albrechts-Universität zu Kiel.

E-mail: Iorenzo.delsavio@iem.uni-kiel-de.

\author{
Alena Buyx \\ Professor of Biomedical Ethics, Institute for Experimental Medicine, \\ Department of Biomedical Ethics, Christian-Albrechts-Universität zu Kiel. \\ E-mail: medizinethik@iem.uni-kiel.de. \\ Barbara Prainsack \\ Professor of Sociology, Department of Social Science, Health \& Medicine, \\ King's College London. E-mail: barbara.prainsack@kcl.ac.uk.
}

\section{Keywords}

Participation, healthcare, patient centred medicine, patient feedback, patient empowerment.

\begin{abstract}
This paper unpacks the notion of public and patient "participation" in medicine and healthcare. It does so by reviewing a series of papers published in the British Medical Journal, and by discussing these in the light of scholarship on participation in political and social theory. We find that appeals to public participation in this series are based on a diverse, potentially contradictory, set of values and motivations. We argue that if these diverse values and motivations are not carefully distinguished, appeals to participation can be an impediment, rather than an enhancement, to greater transparency and public accountability of health research. ${ }^{1}$
\end{abstract}

\footnotetext{
1 We gratefully acknowledge the support of the German Federal Ministry of Education and Research (BMBF grant \#01GP1311).
} 


\section{Table of Contents}

1 Patient and public participation in health research and care ........................................... 3

2 Participation, patient centred care, empowerment in a medical journal ............................... 4

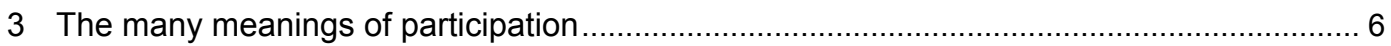

3.1 Patient and public participation $\neq$ patient-centred medicine .......................................... 7

3.2 Patient and public participation $\neq$ patient empowerment ……...................................... 7

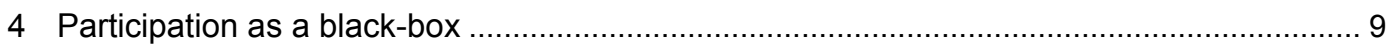

5 Conclusion: Participation in health research and care systems must be unbundled ........... 11

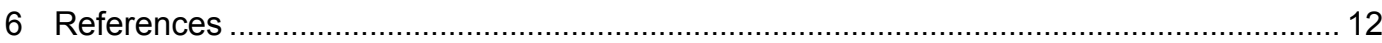

This article draws partly on blog entries that one of the authors (LDS) published at citizenbiomedicine.wordpress.com. Information about our project: citizenbiomedicine.wordpress.com. Please direct correspondence to:

lorenzo.delsavio@iem.uni-kiel.de

\section{MASTHEAD}

\section{Media owner:}

Austrian Academy of Sciences (ÖAW)

Legal person under public law (BGBI 569/1921 idF BGBI I 130/2003)

Dr. Ignaz Seipel-Platz 2, A-1010 Vienna

Editor:

Institute of Technology Assessment (ITA)

Strohgasse 45/5, A-1030 Vienna

www.oeaw.ac.at/ita

ITA manu:scripts appear at irregular intervals and publish working papers and talks from staff members as well as guests. ITA manu:scripts are exclusively made available to the public via the Internet portal "epub.oeaw":

http://epub.oeaw.ac.at/ita/ita-manuscript

ITA-manu:script No.: ITA-16-01 (March/2016)

ISSN-online: 1818-6556

http://epub.oeaw.ac.at/ita/ita-manuscript/ita_16_01.pdf

C 2016 ITA - All rights reserved 


\section{Patient and public participation in health research and care}

Patient and public participation are becoming increasingly institutionalised in medicine and healthcare in rich countries (Hood and Flores 2012, Topol 2015). They are also becoming more central to claims to the legitimacy of these institutions. Citizen participation is an influential social ideal and is seen by many as a remedy for a vast number of social ills (Della Porta 2013), ranging from the lack of trust in political institutions to rising costs in healthcare systems. Science and technology scholars in particular have paid attention to the forms and potentials of participatory politics and acted as advocates of public participation in research and research governance. Some authors explicitly acknowledge the role of Science and Technology Studies in helping to establish and spread participatory practices (Moore 2010). At the same time, concerns are raised about the effectiveness and the allegedly tokenistic nature of participatory initiatives (e.g. Wynne 2006).

As one step to enhance our understanding of how the notion of participation is employed in the field of biomedicine and healthcare, this paper explores the motivations that underpin appeals to public and patient participation in biomedicine within a set of articles published in the British Medical Journal in a series on "Patient Centred Care." ${ }^{2}$ So far, 12 contributions have been published in this series. Out of these 12 , six papers were particularly relevant for our analysis of the motivations for, and values guiding calls and arguments for participation. While the other six papers were interesting empirical case studies, they contained very little or no conceptual or programmatic discussion of participation and were therefore not in the focus of our analysis.

The six articles chosen for detailed analysis cover a broad variety of appeals to participation from different disciplinary perspectives yet written for a similar audience, namely medical professionals. We will start by reviewing these six conceptual or programmatic contributions to the British Medical Journal series "Spotlight on Patient Centred Care", and then develop a typology of different types of motivations and values found in these articles. In doing the latter we will draw upon scholarship on participation in political and social theory.

2 http://www.bmj.com/patient-spotlight. Last accessed 15/03/2016. 


\section{Participation, patient centred care, empowerment in a medical journal}

How is the participation of patients and other "lay" citizens in biomedicine and healthcare conceived in publications dedicated to the topic in a medical journal? What are the main motivations that are seen as driving the adoption of participatory approaches in the organisation of health research and care? How, in these contributions, are patient and public participation related to democratic arguments for participation, patient empowerment, patient advocacy, and social activism?

One of the findings of our literature analysis is that calls for participation in these conceptual and programmatic papers draw rather indiscriminately on various values and motivations that are rooted in different traditions and serve partly contradictory goals. This is already apparent in the introductory web page to the series: ${ }^{3}$

"This spotlight series of articles on patient centred care explores how doctors and patients can work collaboratively to improve the way healthcare is designed and delivered so that it better meets the needs and priorities of patients.

Empowered patients are driving a social movement and spearheading a shift in roles 'as profound as women's liberation, racial equality, gay rights, and disability rights.' ${ }^{4}$ They are capable and motivated to help themselves and other patients to get better care and work with health professionals to improve services ..."

In this quote, the goal of meeting needs and priorities of patients is subsumed under "patient centredness", and linked to emancipatory and civil rights movements as well as improving health outcomes, despite the different values and ideologies that underpin these goals. As will become apparent in the rest of this section, they cannot be easily subsumed under the same "participatory" framework.

Health services analyst Angela Coulter and colleagues (2014), for example, claim that feedback from patients has not yet been used productively for the enhancement of health services. The authors diagnose a chronic failure of healthcare systems to involve patients in treatment decisions, support patient self care, provide empathy and emotional support, and offer well coordinated services. These authors conclude by calling for a "more coordinated approach" to "bring together the various [patient-centred] data sources, enabling more in-depth analysis of these, exploring linkages and overlaps, developing and testing more efficient ways to gather the data, and working out how to ensure that the results are used for quality improvement" ( $p$. 3). They also call for the establishment of a national institute of user experiences. It is apparent that these authors' framing of purposes and means of patient participation is shaped by public management approaches. They do not call for decentralisation and bottom-up patient participation, but instead for the establishment of a centralised institute for the study and elaboration of policy responses to patient feedback. Patients are treated as consumers whose satisfaction levels could be improved by including them more prominently in the design and provision of services. At the same time, these authors' call for a stronger involvement of public actors stands out among the contributions to this British Medical Journal series. All other contributions favour decentralised governance approaches.

3 Available at: http://www.bmj.com/patient-spotlight. Last accessed 15/03/2016.

4 Cf. deBronkart 2015: p. 1. 
Health policy scholar Eugene Nelson and colleagues (2015) also diagnose a failure of healthcare systems to listen to the voices of patients. They argue that both the exploration and the utilisation of patients' views could be enhanced by the use of online networks, and they propose to expand the use of such tools in health systems. They give two examples of what such tools could look like: The first is the Swedish Rheumatology Quality Register, and the second is the U.S. platform for primary care HowsYourHealth.org, which allows patients to "enter all the data themselves, mainly using tick boxes in response to questions" (p. 2). The authors regard these data as a worthy resource as they provide clinicians with standardised information "about patients' function, diagnosis, symptoms, health habits, preventive needs, capacity to self manage chronic conditions, and their experiences of care" (ibid.). Both papers, Coulter and colleagues' as well as Nelson and colleagues', see the enhancement of institutional infrastructures as the best way to increase patient participation; they do not challenge the established hierarchies of power in healthcare systems and medical bureaucracies.

A different perspective is offered by the contribution by health organisation analyst Glenn Robert and a team of patients, caregivers and other analysts of health care. Robert and colleagues do not believe that simple reforms of the healthcare system will enhance participation in a meaningful way (Robert et al. 2015). They believe that "patients can and should take a more direct and ongoing role in identifying, implementing, and evaluating improvements to healthcare services" (p. 1). More specifically, Robert and colleagues argue for "co-creation" of health services by patients, medical professionals, managers, and staff. They draw strongly on managerial theories and methodologies of co-design, without reference to the democratic value of patient activism. In particular, they argue that the reliance on patient surveys and the "lack of critical reflection about the insights provided by survey methods" (p. 2) reveal an "ingrained perception of patients and families as passive sources of data rather than active partners in implementing change" (ibid.). They argue that it is pointless to capture more and more data unless data collection is embedded in practices where patients and families take the lead in implementing changes in the organization of healthcare. Robert and colleagues' suggestions are also clearly influenced by ideas from new public management and theories of co-creation in business and marketing (Zwick, Bonsu, Darmodu 2008). Their overarching aim, similar to previous contributions, is "healthcare quality improvement" (see for instance the concluding section).

The remaining set of papers speak more directly of patient empowerment. The authors see patients' voices as inherently valuable, rather than ascribing mostly instrumental value to them for the enhancement of healthcare. Patient activist Dave deBronkart, internationally known as "e-patient Dave", employs anti-expertocratic arguments to challenge the established division of labour within health systems (deBronkart 2015). He brings his own personal experience to the table, both as a patient leader and as one of the key activists in the area of participatory medicine. DeBronkart also emphasises the role of social networks in empowering patients, and compares patient advocacy and patient communities with other social movements in history, as in the opening quote of the series. He relies on both epistemological and normative assumptions regarding the role of patients, arguing that

"value in medicine depends on knowledge, and in the past two decades the flow of knowledge has undergone a state change, from closed system to open network. Not only is it possible today for patients to see (and tell each other about) the same information that clinicians see; they can also connect with patient peers near and far to discuss topics they care about." (deBronkart 2015: p. 2)

These developments, in deBronkart's words, are "the precursors of autonomy, emancipation, and self determination" (ibid.). 
Physician and British Medical Journal editor Tessa Richards and colleagues (2015) offer a perspective that is complementary to deBronkarts. Richards' paper, co-authored by Angela Coulter and by the vice director of innovation at the patient social network PatientsLikeMe, Paul Wicks, refers directly to deBronkart's work. The paper brings together some of the authors of other papers in the series. Richards et al. argue that the collection of patient feedback, which "should be more rigorous and used to inform practice, not merely collated for research" (p. 1), is made much easier by the wider availability of digital and mobile technologies. Digital technologies in particular have not only "provided new opportunities to harness the energy and expertise of patients," but also fostered patient activism, which is seen to be "growing a social movement" (ibid.). These authors believe this movement to have great importance for healthcare reform, which is sorely needed according to the authors: "Although the global flow of information has transformed many aspects of our lives, it has bypassed chunks of the health sector and it is still hard to get full access to personal health records. But there is welcome news on how the international move to open notes to patients is gaining momentum" (p. 2). They caution, however, against campaigning for "viewing rights" only (i.e. the capacity of patients to access to their medical records), which instead is clearly the key aim of other contributions to the series, particularly Coulter et al. (2014) and Nelson et al. (2015).

In light of these contrasts, in the next section we will unpack the variety of notions of participation that are employed in the series, and categorise the papers accordingly. We will also discuss overlaps and tensions between these notions.

\section{The many meanings of participation}

We have seen that even within the small number of pieces comprising the series on Patient Centred Care in the British Medical Journal, participation is understood to mean different things, and calls for participation are grounded in different conceptual and political traditions. There is a contrast between those who value patients' voices as such, and those who suggest to listen to patients to achieve other goals than increasing patient empowerment. In the latter group we can distinguish further between authors who seek to reach a more systematic uptake of patient opinions on the one hand, and those who aim to broaden and deepen the format and practices of patient engagement. Subsequently we develop a three-fold categorisation of different types of appeals to participation that are made in the papers we analysed. In particular, we propose two conceptual distinctions that may help to order and organise the variety of appeals to participation that we have just reviewed. The first is the distinction between public and patient participation on the one hand and patient-centred medicine on the other, and the second is the difference between participation and empowerment. We will group the papers on the basis of whether or not they make these distinctions. 


\subsection{Patient and public participation $\neq$ patient-centred medicine}

In the form of "patient and public involvement" (PPI), participation has been firmly established within the British National Health Services (NHS) since the early 2000s. Any research within the NHS context needs to consider PPI and involve patients and publics wherever meaningfully possible. PPI is thus a particular approach to the governance of health systems, one that may or may not deliver better patient-centred healthcare in each specific area of the health system, depending on the area, and depending on the criteria used to measure outcomes. (The British NHS has adopted a range of other participatory approaches, including the establishment of a "citizens' council" with advisory roles in the National Institute for Clinical Excellence (NICE) in England from 2002; see Gulland 2002, House of Commons 2007). Patientcentred medicine is a much broader term that spans a wide range of meanings ranging from an approach to healthcare that emphasises respect for patients and focuses on their needs and concerns instead of those of healthcare professionals (Bardes 2012) to attempts to increase patient-reported and patient-generated evidence in medicine (Sacristan 2013). It is thus important to explore in what ways, if at all, a specific participatory practice serves a particular understanding of patient-centred medicine.

\subsection{Patient and public participation $\neq$ patient empowerment}

In literature and practice, patient and public participation are often assumed to lead to patient empowerment. Participation, so the argument typically goes, will strengthen patients' autonomy vis-à-vis medical and health bureaucratic elites, and enhance the agency and control of patients in the healthcare field (e.g. Bravo et al. 2015). But participation is neither the only way to reach the goal of patient empowerment, nor does it always lead to it. For example, public bureaucracies, business management and even innovation practices in both corporate and academic research systems are contributing to an increased involvement of patients in design and executive decisions (Prahalad and Ramaswamy 2004, Gouillart and Hallet 2015). In these cases, the aim is not so much to empower patients, but rather to utilise their knowledge and their collaboration for objectives that are set top-down. This underscores the need to distinguish between the two concepts.

The distinctions between participation, patient-centred care and patient empowerment are treated quite differently in the papers that we have reviewed. Organising these contributions on the basis of the magnitude of adaptations they require to health and research systems results in three groups of participatory appeals, ranging from "moderate reformers," "radical reformers" and "disruptors". We argue that these notions and goals need to be kept apart if we want to avoid the use of the notion of participation as a merely programmatic term that can be used almost arbitrarily to justify greatly different goals and objectives.

a. Moderate reformers accept and employ both of the aforementioned distinctions between PPI, patient-centred medicine and patient empowerment respectively. This group includes medical professionals who seek to improve the responsiveness of health services to patient needs by relying on patient experiences and patient reported outcomes. They do not call for radical "participatory" reforms or participation that takes place outside of established institutions. Instead they try to modify existing infrastructures and processes to be able to draw more strongly on the knowledge, inputs, or expertise of patients. Among the papers that we analysed here, Coulter et al. (2014) and Nelson et al. (2015) belong to this group. 
b. Radical reformers reject distinction 1 (i.e. they do not problematise the relationship between participation and patient-centred medicine) but accept and endorse distinction 2 (that participation $\neq$ patient empowerment). In this group we find mostly medical professionals advocating for public and patient participation on the basis of emerging managerial theories, i.e. the idea of co-creation and co-management. They also use anti-paternalistic language and emphasise values such as equality. However, they are mostly concerned with the quality of services and patient centredness, rather than the idea of delegating control to patients. In the series of papers that we analysed for this article, the paper Robert et al. (2015) is the only one that belongs to this group.

c. Disruptors reject both of the aforementioned distinctions. They believe that patient empowerment and participation are two sides of the same coin, at least, and that participatory medicine is patient-centred medicine. Papers in this group are written by patient advocates and/or people in the private sector. They make strong reference to social movements, and often advocate the utilisation of digital technologies. Richards et al. (2015) and deBronkart (2015) belong to this group.

We can see from this categorisation that even within the small number of contributions in the British Medical Journal series, appeals to participation are motivated by a diverse array of motivations; that these motivations are not always explicit; and that they are sometimes contradictory. Whilst at first sight all of these contributors to the British Medical Journal series seem to be promoting reforms towards greater "patient centredness" in medicine and healthcare, they employ very different understandings of participation and work towards different goals, which we have categorised as "moderate reforms", "radical reforms" and "disruption". In the following section we argue that without making these distinctions, we risk that appeals to public participation are becoming black-boxed, in the sense that participation is seen as an uncontroversial good, even when it serves problematic agendas. Even if in practice the three groups, moderates, radicals and disruptors, may end up supporting similar interventions and policies, they do this for different reasons, and understandings of how healthcare - and society more broadly should ultimately be organised. For this reason, acknowledging differences between different types of calls for more participation is analytically and politically important. The value of clarity with regards to objectives that such calls are serving is emphasised also by advocates of deliberative and participatory democracy in social theory.

In the next section, we will discuss how participation is understood in social theory, paying particular attention to deliberative approaches that favour inclusion and in-depth public discussions about values and aims. These are aims that are jeopardised by the "blackboxing" of participation. 


\section{Participation as a black-box}

Calls for more participation are heard and discussed across the political spectrum (Wynne 2006). Social analyses of the importance of participation in "intermediate bodies", that is organisations of the civil society that are involved in policy making and/or deliver valuable services to the community, ${ }^{5}$ have convinced many policy makers and managers that public participation in domains as varied as urban planning, technology development, and healthcare should be actively nurtured. Some commentators have argued that the promotion of participatory agendas is especially timely now that the role of more traditional belonging to associations, parties, etc. is fading. ${ }^{6}$ Thus, calls for participation in any context of politics and administration are often not motivated by the belief in an intrinsic value of including wider groups of people in debates and decision making, but they are driven by expectations of increasing the "social robustness" or efficiency of interventions, or lowering costs.

Moving from more applied domains to the field of social theory, a key theme in discussions of public participation here is that social processes that exclude public involvement may, as it were, "smuggle" into social processes controversial values, and especially values and aims that are set by groups of technicians, experts or bureaucrats that are beyond public scrutiny. Such exclusion also impinges negatively on the deliberative and thus democratic character of these social processes. Policy making is participatory if citizens - alone or in concert with the groups with which they identify - are able to voice their needs, preferences and desires, and if such voices drive policy making and other social outcomes, within and beyond the formal structures of will formation in a society. For theorists of deliberative democracy in particular, the inclusion of voices from various groups to complement the instruments and processes of representative democracy, and to broaden the visions and options of what policy making could aim at in this way, has intrinsic value (Dryzek 2007). In this literature participation serves the prime objective of opening up political processes that are black-boxed within representative democracies. It lets citizens scrutinise and partake in agenda setting and decision making upon the policies that will influence their lives. Moreover, participation enhances representative democracies by strengthening the connection between the institutions of representative democracy with the concerns and values of citizens, thereby complementing delegative political regimes (Habermas 1999; Hajer and Wagenaar 2000).

Some deliberative theorists argue that, given the pervasive effects of scientific knowledge and technological artefacts have on citizens' opportunities and wellbeing, the political salience of research on public participation in science and technology is increasing. They believe that the lives of citizens are shaped to a larger extent by what happens at the hospital, in the labs, and at the meetings of research fund-setters than by what takes place in the headquarters of representative politics. They argue that citizen participation in purportedly technical discussions in science and technology governance is a key and necessary step towards democratisation and that the traditional division of labour where supposedly political (value-laden) decisions are devolved to representative bodies while technical (value-free) decisions are supposed to be made by experts is becoming untenable (Callon et al. 2001). The very distinction between technical and explicitly "political", value-laden decisions, however, is rejected by these authors,

5 Cf. the classic Putnam (2000) on the decline of social capital in the United States, which has influenced the discussion about participation and its effects in the last decades.

6 In the United Kingdom, participatory ideals are promoted across the political spectrum, ranging from a new language of responsibility within the New Labour discourse (esp. after Giddens 1999) to "big society" ideas in the conservative camp (Norman 2010). 
either because it is considered to be conceptually unclear, or because the traditionally technocratic management of risks has been re-politicised (Jasanoff 2005). In the social studies of science, participation is said to aim at opening up such "black boxes", i.e. the values that are concealed in purportedly technical decisions about research agenda setting and technology development, and subject them to public deliberation (Winner 1993).

Emancipatory politics, such as the advocacy and political work done by patient movements, but also the increase in public scientific literacy - partly thanks to the Open Access and Open Science movements - have increased the visibility of, and the institutional and public receptiveness to, deliberative politics. More recently, anti-hierarchical ideals have also grown out of communication and network technologies that are hoped to foster forms of direct citizen participation in policy-making (O'Connor 2013). Participatory methods and formats are becoming increasingly common, and they are often interspersed with user-centred models of business and management. Against this backdrop, appeals that once appeared radical and associated with social movements - such as data transparency or public access to knowledge and software - have become mainstream. Perhaps ironically, a by-product of increasing openness and the availability of online technologies to share and broadcast opinions and information is that already influential actors gain even more power (Taylor 2014).

Thus, if appeals to, and mechanisms of public participation are not scrutinised to assess what values underpin them and what goals they serve, they run the risk of becoming an additional way to streamline technocratic values into social processes that profoundly shape how people live, their opportunities and their well-being. Participation may itself become a black box. We believe that this risk is particularly salient in medical research and health systems, for a number of reasons. Empowerment and anti-paternalism, are gaining momentum in medical discourse (Friend and Hood 2011). "Insurgent" patient movements have played a role akin to that of social movements in the liberation of patients from perceived and real expert/medical paternalism, especially in the case of conditions whose existence and status was contested, or associated to socially disadvantaged groups, as in the case of HIV patients in the '90s (Epstein 1996). These struggles have turned biomedical research and practice into pioneers of participatory processes. At the same time, health research and health systems are also being transformed by IT technologies that gather individual level data, an area that attracts private companies that extract values from patient data and opinions (Lupton 2012). Citizen participation has emerged as an important complementary tool in scientific research as well, where it is generally called "citizen science" (Lewenstein 2016). Furthermore, appeals for participation accord with controversial efforts of health system reform that are taking place in many countries (Dunston et al. 2009). 


\section{Conclusion: Participation in health research and care systems must be unbundled}

As we have argued in this paper, the diversity of aims supported by advocates of citizen participation should not be black-boxed by participatory language. Only then will we be able to see how proposals for reform in the organisation of biomedicine and healthcare are likely to enhance public participation, improve the quality of patient-centred services, or help realise cost savings.

In an older editorial in the British Medical Journal dedicated to public and patient participation, Paul Hodgkin, chair of the online platform PatientOpinion, and NHS manager Jeremy Taylor (2013) remind us of the large extent to which technologies and social developments are intertwined:

"Where will these trends take us? Medicalization and marketization could stymie moves to a more social and holistic model of care; transparency exposes inadequacy but does not itself generate the drive to overcome it. The digital revolution could empower or enslave the citizen. It is too early to tell. [... and] forces that are driving these shifts are much deeper than health policy" (Hodgkin and Taylor 2013: p. 2).

The contributions to the British Medical Journal series on patient-centred care that we analysed for this paper include references to different and partly contradictory intellectual traditions. Some authors see participation as a useful complement to managerial practices within healthcare; for them, participation is a way to reach the goals set by managers and experts faster or more effectively. Others see participation as a way to increase public scrutiny of decisions about the organisation of healthcare. Yet others consider patient participation valuable because of how it increases the level of knowledge and information of patients. ${ }^{7}$ In this paper, we have identified authors who want to merely use in a more systematic way standardised forms of patient reported outcomes, who even argue for centralised models of management on this basis. Others share the latter's basic and fundamental aim of improving the quality of healthcare, but argue that more robust forms of co-creation are necessary for that pursuit. Only a subset of authors speaks directly about patient empowerment, and even those who do remain silent on the relationship between various models of patient-centred medicine and patient empowerment. Drawing a distinction between "moderate reformers" whose main goal is to become more attentive to patient feedback, "radical reformers" who promote a shift towards processes of co-management, and "disruptors" who see the inclusion of patient perspectives in biomedical practice and research as a goal in its own right, allows us to separate between participatory initiatives that we see as valuable and those that serve goals that we would rather not support. Simply assuming that the participatory turn is "spearheading a shift in roles as profound as women's liberation, racial equality, gay rights, and disability rights" (deBronkart 2015: p. 1) will not help this discussion.

\footnotetext{
7 Patient activist deBronkart (2015), for example, grounds his appeal for participation in the supposed need to make better use of the "diffuse and individual level knowledge" of patients. This way of posing the problem corresponds closely with the rationales underlying the defense of market-based organisation of healthcare on the basis of Hayek (1944).
} 


\section{References}

Bardes CL. Defining "patient-centered medicine”. N Engl J Med. 2012;366(9):782-3.

Beauchamp TL, Childress JF. Principles of biomedical ethics. 7th ed. New York: Oxford University Press; 2013.

Bravo P, Edwards A, Barr PJ, Scholl I, Elwyn G, McAllister M, Cochrane Healthcare Quality Research Group. Conceptualising patient empowerment: a mixed methods study. Health Services Research 2015; 15:252.

Callon M, Lascoumes P, Barthe Y. Acting in an uncertain world: an essay on technical democracy. Cambridge, Mass.: MIT Press; 2009.

Coulter A, Locock L, Ziebland S, Calabrese J. Collecting data on patient experience is not enough: they must be used to improve care. BMJ. 2014;348:g2225.

Crisp N. Patient power needs to be built on strong intellectual foundations: an essay by Nigel Crisp. BMJ. 2012;345:e6177.

deBronkart D. From patient centred to people powered: autonomy on the rise. BMJ. 2015;350:h148.

Della Porta D. Can democracy be saved. Oxford: Polity Press, 2013.

Dryzek JS. Deliberative democracy and beyond: liberals, critics, contestations. Oxford: Oxford University Press; 2002.

Dunston R, Lee A, Boud D, Brodie P, Chiarella M. Co-Production and Health System Reform From Re-Imagining To Re-Making. Aust J Publ Admin. 2009;68(1):39-52.

Epstein S. Impure science: AIDS, activism, and the politics of knowledge. Berkeley: University of California Press; 1996.

Frosch DL. The patient is the most important member of the team. BMJ. 2015;350:g7767.

Giddens A. The third way: the renewal of social democracy. Malden, Mass.: Polity Press; 1999.

Hodgkin P, Taylor J. Power to the people: what will bring about the patient centred revolution? BMJ. 2013;347:f6701.

Hood L, Friend SH. Predictive, personalized, preventive, participatory (P4) cancer medicine. Nat Rev Clin Oncol. 2011;8(3):184-7.

Lupton D. The commodification of patient opinion: the digital patient experience economy in the age of big data. Sociol Health III. 2014;36(6):856-69.

Gulland A. NICE proposals for citizens council condemned by patients. National Institute for Clinical Excellence. BMJ. 2002;325(7361):406.

Gouillart F, Hallet T. Co-creation in government. Stanford social innovation review; Spring 2015 issue.

Hajer MA, Wagenaar H. Deliberative policy analysis: understanding governance in the network society. Cambridge, Mass.: Cambridge University Press; 2003.

Hayek FA. The Use of Knowledge in Society. F. A. Hayek. Am Econ Rev.1945;35(4):519-530.

Habermas J. Between facts and norms: contributions to a discourse theory of law and democracy. Cambridge, Mass.: MIT Press; 1996. 
House of Commons. Patient and Public Involvement in the NHS. London: The Stationery Office Limited, 2007. [Available at: http://www.publications.parliament.uk/pa/cm200607/ cmselect/cmhealth/278/278i.pdf. Last accessed 15/03/2016].

Hood L, Flores M. A personal view on systems medicine and the emergence of proactive P4 medicine: predictive, preventive, personalized and participatory. New biotechnology. 2012;29(6):613-624.

Lewenstein B. Can we understand citizen science? Journal of Science Communication. 2016;15(1):E1-5.

Jasanoff S. Designs on nature: science and democracy in Europe and the United States. Princeton, N.J.: Princeton University Press; 2005.

Moore A. Beyond participation: Opening up political theory in STS. Soc Stud Sci. 2010;40(5):793-9.

Nelson EC, Eftimovska E, Lind C, Hager A, Wasson JH, Lindblad S. Patient reported outcome measures in practice. BMJ. 2015;350:g7818.

Norman J. The Big Society: the Anatomy of the New Politics. Buckingham: The University of Buckingham Press; 2010.

Prahalad CK, Ramaswamy V. The Future of Competition: Co-creating Unique Value with Customers. Boston, MA: Harvard Business School; 2004.

O'Connor D. The Apomediated World: Regulating Research When Social Media Has Changed Research. J Law Med Ethics. 2013;41(2):470-83.

Prainsack B. The powers of participatory medicine. PLoS Biol. 2014;12(4):e1001837.

Putnam RD. Bowling alone: the collapse and revival of American community. New York: Simon \& Schuster; 2000.

Richards T, Coulter A, Wicks P. Time to deliver patient centred care. BMJ. 2015;350:h530.

Robert G, Cornwell J, Locock L, Purushotham A, Sturmey G, Gager M. Patients and staff as codesigners of healthcare services. BMJ. 2015;350:g7714.

Sacristan JA. Patient-centered medicine and patient-oriented research: improving health outcomes for individual patients. BMC Med Inform Decis Mak. 2013;13:6.

Salter B, Zhou YH, Datta S. Hegemony in the marketplace of biomedical innovation: Consumer demand and stem cell science. Soc Sci Med. 2015;131:156-63.

Taylor A. The people's platform: Taking back power and culture in the digital age. New York: Picador; 2014.

Topol E. The patient will see you now: The future of medicine is in your hands. New York: Basic Books, 2015.

Vayena E. The next step in the patient revolution: patients initiating and leading research. BMJ. 2014;349:g4318.

Winner L. Upon Opening the Black-Box and Finding It Empty - Social Constructivism and the Philosophy of Technology. Sci Technol Hum Val. 1993;18(3):362-78.

Wynne B. Public engagement as a means of restoring public trust in science - Hitting the notes, but missing the music? Community Genet. 2006;9(3):211-20.

Zwick D, Bonsu SK, Darmody A. Putting Consumers to Work "Co-creation" and new marketing govern-mentality. J Consum Cult. 2008;8(2):163-96. 


\section{Previously published manu:scripts}

ITA-01-01 Gunther Tichy, Walter Peissl (12/2001): Beeinträchtigung der Privatsphäre in der Informationsgesellschaft. $<w w w .0 e a w . a c . a t / i t a / p d f / i t a \_01 \_01 . p d f>$

ITA-01-02 Georg Aichholzer (12/2001): Delphi Austria: An Example of Tailoring Foresight to the Needs of a Small Country. <www.oeaw.ac.at/ita/pdf/ita_01_02.pdf>

ITA-01-03 Helge Torgersen, Jürgen Hampel (12/2001): The Gate-Resonance Model: The Interface of Policy, Media and the Public in Technology Conflicts. <www.oeaw.ac.at/ita/pdf/ita_01_03.pdf>

ITA-02-01 Georg Aichholzer (1/2002): Das ExpertInnen-Delphi: Methodische Grundlagen und Anwendungsfeld „Technology Foresight". <www.oeaw.ac.at/ita/pdf/ita_02_01.pdf>

ITA-02-02 Walter Peissl (1/2002): Surveillance and Security - A Dodgy Relationship. <www.oeaw.ac.at/ita/pdf/ita_02_02.pdf>

ITA-02-03 Gunther Tichy (2/2002): Informationsgesellschaft und flexiblere Arbeitsmärkte. <www.oeaw.ac.at/ita/pdf/ita_02_03.pdf>

ITA-02-04 Andreas Diekmann (6/2002): Diagnose von Fehlerquellen und methodische Qualität in der sozialwissenschaftlichen Forschung. <www.oeaw.ac.at/ita/pdf/ita_02_04.pdf>

ITA-02-05 Gunther Tichy (10/2002): Over-optimism Among Experts in Assessment and Foresight. $<w w w$. oeaw.ac.at/ita/pdf/ita_02_05.pdf>

ITA-02-06 Hilmar Westholm (12/2002): Mit eDemocracy zu deliberativer Politik? Zur Praxis und Anschlussfähigkeit eines neuen Mediums. <www.oeaw.ac.at/ita/pdf/ita_02_06.pdf>

ITA-03-01 Jörg Flecker und Sabine Kirschenhofer (01/2003): IT verleiht Flügel? Aktuelle Tendenzen der räumlichen Verlagerung von Arbeit. <www.oeaw.ac.at/ita/pdf/ita_03_01.pdf>

ITA-03-02 Gunther Tichy (11/2003): Die Risikogesellschaft - Ein vernachlässigtes Konzept in der europäischen Stagnationsdiskussion. <www.oeaw.ac.at/ita/pdf/ita_03_02.pdf>

ITA-03-03 Michael Nentwich (11/2003): Neue Kommunikationstechnologien und Wissenschaft Veränderungspotentiale und Handlungsoptionen auf dem Weg zur Cyber-Wissenschaft. <www.oeaw.ac.at/ita/pdf/ita_03_03.pdf>

ITA-04-01 Gerd Schienstock (1/2004): Finnland auf dem Weg zur Wissensökonomie - Von Pfadabhängigkeit zu Pfadentwicklung. <www.oeaw.ac.at/ita/pdf/ita_04_01.pdf>

ITA-04-02 Gunther Tichy (6/2004): Technikfolgen-Abschätzung: Entscheidungshilfe in einer komplexen Welt. <www.oeaw.ac.at/ita/pdf/ita_04_02.pdf>

ITA-04-03 Johannes M. Bauer (11/2004): Governing the Networks of the Information Society - Prospects and limits of policy in a complex technical system. <www.oeaw.ac.at/ita/pdf/ita_04_03.pdf>

ITA-04-04 Ronald Leenes (12/2004): Local e-Government in the Netherlands: From Ambitious Policy Goals to Harsh Reality. <www.oeaw.ac.at/ita/pdf/ita_04_04.pdf>

ITA-05-01 Andreas Krisch (1/2005): Die Veröffentlichung des Privaten - Mit intelligenten Etiketten vom grundsätzlichen Schutz der Privatsphäre zum Selbstschutz-Prinzip. <www.oeaw.ac.at/ita/pdf/ita_05_01.pdf>

ITA-05-02 Petra Grabner (12/2005): Ein Subsidiaritätstest - Die Errichtung gentechnikfreier Regionen in Österreich zwischen Anspruch und Wirklichkeit. <epub.oeaw.ac.at/ita/ita-manuscript/ita_05_02.pdf>

ITA-05-03 Eva Buchinger (12/2005): Innovationspolitik aus systemtheoretischer Sicht - Ein zyklisches Modell der politischen Steuerung technologischer Innovation. <www.oeaw.ac.at/ita/pdf/ita_05_03.pdf>

ITA-06-01 Michael Latzer (6/2006): Medien- und Telekommunikationspolitik: Unordnung durch Konvergenz - Ordnung durch Mediamatikpolitik. <epub.oeaw.ac.at/ita/ita-manuscript/ita_06_01.pdf>

ITA-06-02 Natascha Just, Michael Latzer, Florian Saurwein (9/2006): Communications Governance: Entscheidungshilfe für die Wahl des Regulierungsarrangements am Beispiel Spam. <epub.oeaw.ac.at/ita/ita-manuscript/ita_06_02.pdf>

ITA-06-03 Veronika Gaube, Helmut Haberl (10/2006): Sozial-ökologische Konzepte, Modelle und Indikatoren nachhaltiger Entwicklung: Trends im Ressourcenverbrauch in Österreich. <epub.oeaw.ac.at/ita/ita-manuscript/ita_06_03.pdf>

ITA-06-04 Maximilian Fochler, Annina Müller (11/2006): Vom Defizit zum Dialog? Zum Verhältnis von Wissenschaft und Öffentlichkeit in der europäischen und österreichischen Forschungspolitik. <epub.oeaw.ac.at/ita/ita-manuscript/ita_06_04.pdf>

ITA-06-05 Holger Floeting (11/2006): Sicherheitstechnologien und neue urbane Sicherheitsregimes. <epub.oeaw.ac.at/ita/ita-manuscript/ita_06_05.pdf>

ITA-06-06 Armin Spök (12/2006): From Farming to „Pharming” - Risks and Policy Challenges of Third Generation GM Crops. <epub.oeaw.ac.at/ita/ita-manuscript/ita_06_06.pdf>

ITA-07-01 Volker Stelzer, Christine Rösch, Konrad Raab (3/2007): Ein integratives Konzept zur Messung von Nachhaltigkeit - das Beispiel Energiegewinnung aus Grünland.

<epub.oeaw.ac.at/ita/ita-manuscript/ita_07_01.pdf>

ITA-07-02 Elisabeth Katzlinger (3/2007): Big Brother beim Lernen: Privatsphäre und Datenschutz in Lernplattformen. <epub.oeaw.ac.at/ita/ita-manuscript/ita_07_02.pdf>

ITA-07-03 Astrid Engel, Martina Erlemann (4/2007): Kartierte Risikokonflikte als Instrument reflexiver Wissenspolitik. <epub.oeaw.ac.at/ita/ita-manuscript/ita_07_03.pdf>

ITA-07-04 Peter Parycek (5/2007): Gläserne Bürger - transparenter Staat? Risiken und Reformpotenziale des öffentlichen Sektors in der Wissensgesellschaft. <epub.oeaw.ac.at/ita/ita-manuscript/ita_07_04.pdf>

ITA-07-05 Helge Torgersen (7/2007): Sicherheitsansprüche an neue Technologien - das Beispiel Nanotechnologie. <epub.oeaw.ac.at/ita/ita-manuscript/ita_07_05.pdf>

ITA-07-06 Karen Kastenhofer (9/2007): Zwischen „schwacher“ und „starker“ Interdisziplinarität. Die Notwendigkeit der Balance epistemischer Kulturen in der Sicherheitsforschung zu neuen Technologien.

<epub.oeaw.ac.at/ita/ita-manuscript/ita_07_06.pdf> 
ITA-07-07 Ralf Lindner, Michael Friedewald (9/2007): Gesellschaftliche Herausforderungen durch „intelligente Umgebungen. Dunkle Szenarien als TA-Werkzeug. <epub.oeaw.ac.at/ita/ita-manuscript/ita_07_07.pdf>

ITA-07-08 Alfons Bora (11/2007): Die disziplinären Grundlagen der Wissenschaft. <epub.oeaw.ac.at/ita/ita-manuscript/ita_07_08.pdf>

ITA-08-01 Alexander Degelsegger (5/2008): „Frames“ in sozialwissenschaftlichen Theorieansätzen. Ein Vergleich aus der Perspektive der Technikforschung. <epub.oeaw.ac.at/ita/ita-manuscript/ita_08_01.pdf>

ITA-08-02 Jens Hoff (11/2008): Can The Internet Swing The Vote? Results from a study of the 2007 Danish parliamentary election. <epub.oeaw.ac.at/ita/ita-manuscript/ita_08_02.pdf>

ITA-09-01 Georg Aichholzer, Doris Allhutter (2/2009): e-Participation in Austria: Trends and Public Policies. <epub.oeaw.ac.at/ita/ita-manuscript/ita_09_01.pdf>

ITA-09-02 Michael Nentwich (11/2009): Cyberscience 2.0 oder 1.2? Das Web 2.0 und die Wissenschaft. <epub.oeaw.ac.at/ita/ita-manuscript/ita_09_02.pdf>

ITA-09-03 Hilmar Westholm (12/2009): Wandel der Formen politischer Partizipation und der Beitrag des Internet. Schlussfolgerungen aus Bevölkerungsbefragungen in Deutschland. <epub.oeaw.ac.at/ita/ita-manuscript/ita_09_03.pdf>

ITA-10-01 Iris Eisenberger (12/2010): Kleine Teile, große Wirkung? Nanotechnologieregulierung in der Europäischen Union. <epub.oeaw.ac.at/ita/ita-manuscript/ita_10_01.pdf>

ITA-10-02 Alexander Degelsegger and Helge Torgersen (12/2010): Instructions for being unhappy with PTA. The impact on PTA of Austrian technology policy experts' conceptualisation of the public. <epub.oeaw.ac.at/ita/ita-manuscript/ita_10_02.pdf>

ITA-10-03 Ernest Braun (12/2010): The Changing Role of Technology in Society. <epub.oeaw.ac.at/ita/ita-manuscript/ita_10_03.pdf>

ITA-10-04 Fritz Betz (12/2010): E-Partizipation und die Grenzen der Diskursethik. <epub.oeaw.ac.at/ita/ita-manuscript/ita_10_04.pdf>

ITA-11-01 Peter Parycek, Judith Schoßböck (1/2011): Transparency for Common Good. Offener Zugang zu Information im Kontext gesellschaftlicher und strategischer Spannungsfelder. <epub.oeaw.ac.at/ita/ita-manuscript/ita_11_01.pdf>

ITA-11-02 Georg Aichholzer und Doris Allhutter (6/2011): Online forms of political participation and their impact on democracy. <epub.oeaw.ac.at/ita/ita-manuscript/ita_11_02.pdf>

ITA-11-03 Mahshid Sotoudeh, Walter PeissI, Niklas Gudowsky, Anders Jacobi (12/2011): Long-term planning for sustainable development. CIVISTI method for futures studies with strong participative elements. <epub.oeaw.ac.at/ita/ita-manuscript/ita_11_03.pdf>

ITA-12-01 Xiao Ming (1/2012): e-Participation in Government Decision-Making in China. Reflections on the Experience of Guangdong Province. <epub.oeaw.ac.at/ita/ita-manuscript/ita_12_01.pdf>

ITA-12-02 Stephan Bröchler, Georg Aichholzer, Petra Schaper-Rinkel (Hrsg.) (9/2012): Theorie und Praxis von Technology Governance. <epub.oeaw.ac.at/ita/ita-manuscript/ita_12_02_Sondernummer.pdf>

ITA-12-03 Iris Eisenberger (10/2012): EU-Verhaltenskodex Nanotechnologie: Rechtsstaatliche und demokratische Aspekte. <epub.oeaw.ac.at/ita/ita-manuscript/ita_12_03.pdf>

ITA-12-04 Julia Haslinger, Christiane Hauser, Peter Hocke, Ulrich Fiedeler (10/2012): Ein Teilerfolg der Nanowissenschaften? Eine Inhaltsanalyse zur Nanoberichterstattung in repräsentativen Medien Österreichs, Deutschlands und der Schweiz. <epub.oeaw.ac.at/ita/ita-manuscript/ita_12_04.pdf>

ITA-13-01 Helge Torgersen, Alexander Bogner, Karen Kastenhofer (10/2013): The Power of Framing in Technology Governance: The Case of Biotechnologies. <epub.oeaw.ac.at/ita/ita-manuscript/ita_13_01.pdf>

ITA-13-02 Astrid Mager (11/2013): In search of ideology. Socio-cultural dimensions of Google and alternative search engines. <epub.oeaw.ac.at/ita/ita-manuscript/ita_13_02.pdf>

ITA-13-03 Petra Wächter (12/2013): Aspekte einer nachhaltigen Energiezukunft. <epub.oeaw.ac.at/ita/ita-manuscript/ita_13_03.pdf>

ITA-14-01 Renate Mayntz (8/2014): Technikfolgenabschätzung - Herausforderungen und Grenzen. <epub.oeaw.ac.at/ita/ita-manuscript/ita_14_01.pdf>

ITA-14-02 Michael Narodoslawsky (11/2014): Utilising Bio-resources: Rational Strategies for a Sustainable Bio-economy. <epub.oeaw.ac.at/ita/ita-manuscript/ita_14_02.pdf>

ITA-14-03 Petra Wächter (12/2014): Ökonomik in der Technikfolgenabschätzung - eine Bestandsaufnahme <epub.oeaw.ac.at/ita/ita-manuscript/ita_14_03.pdf>

ITA-15-01 Reinhard Grünwald (5/2015): Stromnetze: Bedarf, Technik, Folgen. <epub.oeaw.ac.at/ita/ita-manuscript/ita_15_01.pdf>

ITA-15-02 Christine Chaloupka, Robert Kölbl, Wolfgang Loibl, Romain Molitor, Michael Nentwich, Stefanie Peer, Ralf Risser, Gerd Sammer, Bettina Schützhofer, Claus Seibt (6/2015): Nachhaltige Mobilität aus sozioökonomischer Perspektive - Diskussionspapier der Arbeitsgruppe „Sozioökonomische Aspekte“ der ÖAW-Kommission „Nachhaltige Mobilität“. <epub.oeaw.ac.at/ita/ita-manuscript/ita_15_02.pdf>

ITA-15-03 Sabine Pfeiffer (10/2015): Auswirkungen von Industrie 4.0 auf Aus- und Weiterbildung. <epub.oeaw.ac.at/ita/ita-manuscript/ita_15_03.pdf>

ITA-15-04 Sabine Pfeiffer (11/2015): Effects of Industry 4.0 on vocational education and training <epub.oeaw.ac.at/ita/ita-manuscript/ita_15_04.pdf>

ITA-16-01 Lorenzo Del Savio, Alena Buyx \& Barbara Prainsack (3/2016): Opening the black box of participation in medicine and healthcare. <epub.oeaw.ac.at/ita/ita-manuscript/ita_16_01.pdf> 